\title{
VIEWPOINTS
}

\section{Toward Islamic Banking Without Tawarruq}

\author{
Mohammad Mahbubi Ali *
}

Islamic financial products have evolved and developed remarkably from simple and straightforward structures to highly sophisticated and multifaceted instruments. During the 1980s and 1990s, Islamic financial products were dominated by deposits and savings, syndicated project financing, Shari'ahcompliant stocks and mutual funds. The last two decades have witnessed the unveiling of more complicated structures, including various sukuk models, derivatives, Islamic structured products, Islamic hedge funds, and others. Most, though not all, of these replicate conventional products, splicing together nominate contracts from the Islamic figh legacy with a few modern modifications to meet legal requirements and to become 'Shari'ah-compliant'.

Tawarruq, commonly known as commodity murabahah, is a financial instrument that has facilitated the launch of unprecedented and sophisticated Islamic financial products, ranging from deposit and financing instruments, to liquidity management and debt restructuring, sovereign and private sukuk structuring, risk management and hedging instruments. The word tawarruq is derived from the Arabic root word wariq, meaning coined silver. From this literal meaning, the technical definition of tawarruq can be understood to be an intention to enter into a contract not to obtain a commodity, but rather to attain silver or liquidity. It is an arrangement involving a series of successive sale contracts whereby a person purchases a commodity from a seller on a deferred basis and subsequently sells it to a party other than the original seller on a cash basis for the purpose of obtaining liquidity.

Tawarruq has gained wide acceptance amongst industry players because its built-in features and characteristics can deliver similar economic outcomes to those of conventional products. Over the last few years, the concept has evolved to become one of the most ubiquitous amongst Malaysian Islamic banking products, responding quickly to the Bank Negara Malaysia (BNM) 2012 circular on bay' 'inah (sale and buy-back), which substantially tightened the Shari'ah 
requirements of bay' 'inah products. This circular indirectly urged Malaysian Islamic banks (IBs) to shun bay' 'inah and explore other alternatives. Some banks have even phased out bay' 'inah-based products from their portfolios as a result.

A 2015 survey of "Shari'ah non-compliant events in Islamic banks in the practice of tawarruq financing in Malaysia" revealed that tawarruq-based products dominate the Malaysian Islamic banking industry, representing more than $80 \%$ of the total financing portfolio of 3 Malaysian IBs, between $61 \%-80 \%$ of 6 IBs, and between $40-60 \%$ of 2 IBs. The rest applied tawarruq in relatively smaller portions, constituting less than $40 \%$ of their total financing portfolios.

It was also found that IBs have used tawarruq to structure various types of deposit and financing products, with 15 Malaysian Islamic commercial banks extensively using tawarruq for term deposit products. Moreover, $73 \%$ of them also employed it for treasury products while also exploring the application of the concept for current accounts and saving accounts (CASA). In terms of financing products, $80 \%$ of Malaysian IBs applied the tawarruq concept to personal financing and term financing, whereas $60 \%$ employed it to home/property financing. Others used the concept for vehicle financing and Islamic credit card facilities.

Nevertheless, the extensive use of tawarruq in Islamic financial institutions (IFIs) has stirred a plethora of contentious queries from both Shari'ah scholars and Muslim economists. The fact that tawarruq is designed to merely mirror the characteristics of conventional products challenges the view that IFIs offer a genuine alternative to conventional finance. As a result, the prospect that IFIs can offer solutions to the economic problems caused by conventional finance are dimming. In addition, the International Islamic Fiqh Academy, a subsidiary organ of the Organisation of Islamic Cooperation (OIC), in its 19th meeting held in Sharjah (United Arab Emirates) in 2009, ended with a resolution that the modern practice of organised tawarruq is impermissible. This is mainly due to the absence of a true and genuine transaction. Rather, a series of transactions between the bank and the customer is executed simultaneously in exchange for a financial obligation. This arrangement has been designed to offer quick cash to the customer for a higher amount in the future, an arrangement which is considered to contain the element of riba. The Accounting and Auditing Organisation for Islamic Financial Institutions (AAOIFI), in its Shari'ah Standard Number 30 Paragraph 5/1, 2008, clearly states that tawarruq should only be employed as a last resort when an institution faces a liquidity shortage that could harm its sustainability. It should not be used as a mode of investment or financing for the purpose of profit making.

Shari'ah scholars have identified four major Shari'ah issues in the modern practice of organised tawarruq. Firstly, many commodities used in tawarruq 
practice are defective. Sheikh Ali al-Qaradaghi has revealed that he came across one tawarruq transaction on the international commodity market in which the underlying commodity was defective aluminium from Russia that had been in storage for more than ten years. This commodity was being used because it could not otherwise be sold on the market. Secondly, tawarruq legal documents may be embedded with a clause restricting the customer from taking delivery of the commodity purchased. This is particularly true in the case of tawarruq transactions conducted via the London Metal Exchange (LME). The Standard Operating Procedure (SOP) in LME has been designed in such a way that a buyer should not have the intention to take delivery. This is because LME is a derivative platform for transactions involving futures, options, traded averageprice options and LME swaps where, in most cases, physical delivery is not required. Thirdly, the commodity rarely gets physically transferred from seller to buyer. A 'netting arrangement' mechanism, which has become standard practice in the LME market, further substantiates the fact that delivery and possession do not actually take place. Fourthly, the inclusion of agency in the tawarruq arrangement makes the contract similar to the prohibited 'inah. The involvement of IFIs in arranging the second sale has been used to question the authenticity of the whole tawarruq arrangement. For that reason, the Kuwait Finance House (KFH), though permitting the use of tawarruq for banking products, strongly advocates the removal of agency elements in the tawarruq structure to avoid any resemblance to riba.

On the operational side, tawarruq assumes a relatively high degree of Shari'ah non-compliance risk compared to other contracts. This is mainly because it involves a series of sale contracts conducted in succession. A 2015 survey by the author found that the improper sequence of these contracts (i.e. sale of an asset before the bank acquires it from the trader) constitutes the most frequent Shari'ah non-compliant (SNC) event in Malaysian IBs. Therefore, IBs have to institute more prudent Shari'ah risk management strategies and clearer standard operational procedures. Proper review and due diligence are also crucial before the execution of a contract so as to ensure that the arrangement does not reflect a mere exchange of papers.

Realising the Shari'ah compliance concerns and operational challenges surrounding the application of tawarruq in IBs, it is proposed that the Malaysian authorities and Shari'ah committees establish certain parameters and limitations in the use of tawarruq. The concept should only be allowed as a last option, where no other alternative concepts are available. Other concepts, such as ijarah al-khadamat (lease of future services) and salam (forward sale), can be explored as alternatives to tawarruq. This is for a number of reasons. Firstly, the practice of tawarruq in IBs is disputed among Shari'ah scholars across jurisdictions. This 
impedes the Malaysian government agenda for the internationalisation of Islamic finance. Secondly, the overwhelming use of tawarruq does not substantially add to either the IFI value proposition or economic growth due to the nature of the debt inherent to the concept. Finally, tawarruq requires a more prudent risk mitigation mechanism because it is prone to exposure to a large volume of SNC events.

* Mohammad Mahbubi Ali is a Research Fellow at the International Institute of Advanced Islamic Studies (IAIS) Malaysia. He can be contacted at mahbubi@, iais.org.my. 